\title{
PEMBELAJARAN SEJARAH YANG EFEKTIF DI SMA NEGERI 1 MLATI SLEMAN
}

\section{Effective History Learning at SMA Negeri 1 Mlati Sleman}

\author{
Inna Felinda,Sugiyono \\ Universitas Negeri Yogyakarta, \\ innafelindastarjogja@gmail.com, sugiyono_1953@yahoo.com
}

\begin{abstract}
Abstrak
INNA FELINDA. Pembelajaran Sejarah yang Efektif di SMA Negeri 1 Mlati Sleman.Tesis. Yogyakarta: Program Pascasarjana Universitas Negeri Yogyakarta, 2017.
\end{abstract}

Penelitian ini bertujuan untuk mengetahui: (1) penerapan metode pembelajaran, (2) penerapan model pembelajaran, (3) penerapan evaluasi pembelajaran, (4) faktor yang mendukung pembelajaran sejarah yang efektif, (5) faktor yang menghambat pembelajaran sejarah yang efektif, (5) tingkat penyerapan siswa dalam pembelajaran sejarah, dan (7) peran guru dalam pembelajaran sejarah di SMA Negeri 1 Mlati Sleman.

Penelitian merupakan penelitian kualitatif. Informan kunci dalam penelitian ini adalah Kepala Sekolah, Wakil Kepala Sekolah Bidang Kurikulum, Guru Bidang Studi Sejarah, dan Siswa Jurusan IPS dan IPA Kelas XI. Teknik pengumpulan data meliputi wawancara, observasi, dan dokumentasi. Keabsahan data menggunakan trianggulasi data. Teknik analisis data menggunakan model analisis data Miles dan Huberman yaitu jaringan kausal. Untuk dapat menggambarkan makna hubunganhubungan antar faktor dalam penelitian ini, menggunakan metode fishbone diagram.

Hasil penelitian menunjukkan bahwa: (1) pembelajaran sejarah di SMA Negeri 1 Mlati Sleman, meliputi kegiatan memilih, menetapkan, mengembangkan metode untuk mencapai hasil pengajaran yang diinginkan. Pemilihan, penetapan, dan pengembangan metode ini didasarkan pada kondisi pengajaran yang ada khususnya pada pembelajaran sejarah. (2) Salah satu model pembelajaran sejarah yang digunakan adalah gambar maupun video yang dilakukan agar gambar dapat diurutkan menjadi urutan logis. (3) Evaluasi pembelajaran sudah dipersiapkan pada awal atau waktu pembuatan program semester kecuali untuk evaluasi atau ujian akhir sekolah direncanakan atau diambil waktu persiapan evaluasi harian dan setiap sub pokok bahasan. Untuk evaluasi ada tes tulis, tes lisan (tanya jawab). (4) Faktor yang mendukung pembelajaran, yaitu strategi pembelajaran yang disampaikan dapat diterima dengan baik oleh siswa dan menumbuhkan minat belajar siswa, karena minat sangat mempengaruhi dalam proses dan hasil belajar. (5) Faktor yang menghambat pembelajaran sejarah di antaranya kemampuan siswa yang berbeda-beda sehingga dibutuhkan pendekatan pembelajaran secara individu kepada setiap siswa. Hambatan lain berupa sumber dan alat-alat pembelajaran seperti laboratorium sejarah yang belum dimiliki (6) Tingkat penyerapan siswa dalam pembelajaran sejarah, sangat berkaitan dengan pemahaman siswa. Dalam proses pembelajaran, setiap individu siswa memiliki kemampuan yang berbedabeda dalam memahami apa yang dia pelajari. (7) Peran guru dalam pembelajaran sejarah, meliputi memberikan motivasimotivasi kepada siswa untuk lebih semangat dalam belajar. Menjalin komunikasi yang baik antar guru dan siswa.

Kata Kunci: pembelajaran sejarah yang efektif, SMA N 1 Mlati 


\begin{abstract}
INNA FELINDA. Effective History Learning at SMA Negeri 1 Mlati Sleman. Thesis. Yogyakarta: Graduate Scholl, Yogyakarta State University, 2017.

This study aimed to determine: (1) the application of learning methods, (2) the application of learning models, (3) the application of learning evaluation, (4) factors that support effective history learning, (5) factors that inhibit effective historical learning, (6) the absorption rate of students in learning history, and (7) the role of teachers in learning history of SMA Negeri 1 Mlati Sleman.

This research is a qualitative. Key informant in this research were Headmaster, Deputy Headmaster of Curriculum Field, Teachers of History Study Course, and Students of IPS Department and IPA Class XI. Data collection techniques included interviews, observation, and documentation. Data validity used data triangulation. Data analysis technique used Miles and Huberman analysis model that was causal network. To be able to describe the meaning of relationships between factors in this study, using the method of fishbone diagram was used.

The results showed that: (1) history learning of SMA Negeri 1 Mlati Sleman, included activities to select, establish, develop methods to achieve the desired teaching outcomes. The selection, determination, and development of this method were based on existing teaching conditions especially on historical learning. (2) One of the historical learning models used was images and video that were done so that images could be sorted into a logical sequence. (3) Evaluation of learning has been prepared at the beginning or time of programming of the semester except for evaluation or the final examination of the school was planned or taken preparation time of daily evaluation of each sub subject. For evaluation there were a written test, oral test (question and answer). (4) Factors that support the learning was that the learning strategy that was delivered could be received well by students and foster interest in student's learning, because the interest was very influential in the process and learning outcomes. (5) Factors that hamper the learning of history included the diffent ability of students so that an individual learning approach was required for each student. Other obstacles are resources and learning tools such as history labs that had not been owned. (6) The absorption rate of students in learning history was closely related to students' understanding. In the learning process, each individual student had different abilities in understanding what he or she was learning. (7) The role of teachers in learning history included to providing motivation to students to be more enthusiastic in learning and stablishing good communication between teachers and students.
\end{abstract}

Keywords: effective history learning, SMA N 1 Mlati 


\section{Pendahuluan}

Efektifitas dalam Kamus Besar Bahasa Indonesia (Poerwandarminta, W.J.S. 1990:266) kata keefektifan berasal dari kata efektif yang mempunyai arti adanya efeknya (akibatnya, pengaruhnya, kesannya, manjur atau mujarab, dapat membawa hasil. Jadi keefektifan adalah adanya kesesuaian antara orang yang melaksanakan tugas dengan sasaran yang dituju. Keefektifan adalah bagaimana suatu organisasi berhasil mendapatkan dan mamanfaatkan sumber daya usaha mewujudkan tujuan operasional. Dimaksudkan dalam pembelajaran terlaksananya semua tugas pokok, tercapinya tujuan, ketepatan waktu dan adanya partisipasi aktif dari dari peserta didik sehingga tercapai hasil yang sesuai dengan yang diharapkan.

Efektifitas adalah suatu ukuran yang menyatakan berapa besar rasio hasil target baik kuantitas dalam kurun waktu tertentu dicapai semakin besar rasio yang dicapai, semakin tinggi tingkat efektifitasnya (Riduwan, 2010;335). Menurut Taylor ciri-ciri efektifitas sekolah (Riduwan, 2010: 35) sebagai berikut: 1) tujuan sekolah dinyatakan secara jelas dan spesifik; 2) pelaksanaan kepemimpinan pendidikan yang kuat oleh kepala sekolah; 3) eskpektasi guru dan staf tinggi; 4) ada kerjasama kemitraan sekolah, orang tua dan masyarakat; 5) adanya iklim positif dan kondusif bagi siswa untuk belajar; 6) Kemajuan siswa sering dimonitor; 7) menekankan pada keberhasialan siswa dalam mencapai keterampilan aktifitas yang esensial.

Pembelajaran merupakan perilaku yang hendak dicapai yang dapat dikerjakan oleh siswa pada kondisi dan tingkat kompetensi tertentu. Menurut Nana Syaodih Sukmadinata (2014:131) kegiatan belajar mengajar tidak dapat dilepaskan dari belajar, sebab keduanya merupakan dua sisi dari sebuah mata uang. Mengajar merupakan suatu upaya yang idlakukan guru agar siswa belajar. Syaiful Vahri dan Aswan Zain menjelaskan bahwa (2006:37) kegiatan belajar mengajar adalah suatu kondisi yang dengan sengaja diciptakan oleh guru dengan tujuan membelajarkan siswa, dimana guru sebagai pelajar dan siswa sebagai anak didik. Kesatuan atau perpaduan kedua unsur ini maka lahirlah interkasi yang edukatif dengan memanfaatkan bahan sebagai mediumnya.
Pembelajaran merupakan suatu proses yang dilakukan oleh individu untuk memperoleh suatu perubahan perilaku yang baru secara keseluruhan, sebagai hasil dari pengalaman individu itu sendiri dalam interaksi dengan lingkungannya. Menurut Rochmat Wahab (2009: 4) pembelajaran orang dewasa memang mendorong peserta didik untuk terlibat pada persoalan dunia riil dan mengaitkan belajar dengan kebutuhan atau tujuannya, serta mengaitkan materi belajar dengan masa lalunya, sehingga peserta didik benar-benar merasakan asyik dalam belajar. Dalam situasi yang begini, peserta didik sungguh menjadi sumber utama proses pembelajaran.

Menurut Ravi (2010: 6) "The effectiveness of a model is heavily dependent on the context in which applied; instructional design method are situational and not universal". Guru menjadi pilar utama yang berinteraksi langsung dengan siswa dalam pembelajaran. Salah satu syarat guru yang berkualitas adalah guru yang memiliki kompetensi pedagogik. Kompetensi pedagogic merupakan kemampuan dalam pengelolaan peserta didik, yaitu mampu melaksanakan pembelajaran yang mendidik dengan suasana dialogis dan interaktif, sehingga pembelajaran menjadi aktif, inovatif, kreatif, efektif, dan menyenangkan. Hal ini juga ditegaskan oleh (Warni Tune Sumardan Intan Abdul Razak (2015: 3) bahwa guru menempati posisi strategis dalam perwujudan pendidikan yang optimal. Oleh karena itu guru dituntut meningkatkan profesionalisme dan keterampilannya dalam pembelajaran. Menurut Ahmad Baedowi, dkk. (2015: 1) penyelenggaraan pembelajaran yang baik di lembaga-lembaga pendidikan formal, informal atau bahkan dalam pendidikan tradisional dalam keluarga maupun komunitas, pada hakikatnya selalu merupakan proses belajar mengajar yang bertumpu pada keniscaya anakan laku perubahan.

Pendidikan sejarah di era global dewasa ini menghadapi tantangan dan dituntut kontribusinya untuk lebih menumbuhkan kesadaran sejarah, baik pada posisinya sebagai anggota masyarakat maupun warga negara, serta mempertebal semangat kebangsaan dan rasa cinta tanah air tanpa mengabaikan rasa kebersamaan dalam 
kehidupan antar bangsa di dunia (ErlinaWiyanarti, 2010: 2). Di Indonesia, sejarah telah menjadi salah satu mata pelajaran wajib dalam kurikulum SMA kelas X, XI IPA dan XI IPS. Namun pembelajaran sejarah di banyak sekolah tidak lebih dari transfer ilmu guru kesiswa di dalam kelas melalui komunikasi satu arah. Siswa hanya menjadi objekpasif yang mempunyai kewajiban menghafal catatan yang didiktekan guru supaya bisa menjawab soal-soal yang akan diujikan. Metode pembelajaran sejarah semacam ini telah menjadikan pelajaran sejarah membosankan, karena tidak memberikan sentuhan emosional, siswa merasa tidak terlibat aktif dalam proses pembelajaran. Metode pembelajaran yang kaku berakibat buruk untuk jangka waktu panjang dan berpotensi memunculkan generasi yang mengalami "amnesia sejarah" yaitu melupakan sejarah bangsa sendiri.

Pembelajaran sejarah di sekolah yang sebagai rangkaian fakta-fakta yang berupa urutan tahun, tokoh dan peristiwa belaka yang jauh dari lingkungan social peserta didik. Pembelajaran sejarah, tidak hanya terfokus pada hasil belajar siswa khususnya pada aspek akademis saja. Siswa menganggap sejarah tidak menarik dan membosankan karea materi yang monoton. Siswa tidak berminat membaca buku sejarah kerena menganggap pelajaran sejarah tidak masuk Ujian Nasional. Guru membeberkan waktu yang singkat sedangkan materinya banyak, sehingga saat menerangkan secara cepat untuk mencapai tujuan pembelajaran. Kurikulum isinya hanya mengulang saja. Dengan demikian kajian materi Sejarah secara kritis dan analistis hanya seperti kosong. Siswa banyak yang menggampangkan pelajaran sejarah. Belum tersedianya laboraturiom sejarah bahkan bahan ajar yang kurang lengkap.

Tatta Herawati Daulae (2014: 132) menjelaskan bahwa pembelajaran yang efektif ini merupakan salah satu faktor yang dapat menentukan keberhasilan proses pembelajaran. Hal ini harus menjadi perhatian dosen dan guru dalam rangka meningkatkan mutu pembelajaran, maka dalam tulisan ini akan menguraikan indikator-indikator yang harus dilaksanakan dalam menciptakan pembelajaran yang efektif. Lebih lanjut dijelaskan oleh Suyono (2014: 203) pembelajaran efektif dan produktif adalah kegiatan pembelajaran yang secara terencana membantu siswa mencapai dua tujuan utama, yakni mencapai tujuan pembelajaran secara optimal dan sekaligus mengondisikan siswa produktif dalam menghasilkan gagasangagasan.

\section{Metode Penelitian}

\section{Jenis Penelitian}

Penelitian ini menggunakan pendekatan kualitatif analistik.

\section{Waktu dan Tempat Penelitian}

Waktu Penelitian ini dilaksanakan selama tiga bulan yang dimulai pada Januari 2017 sampai dengan Maret 2017. Penelitian ini berlokasi di SMA Negeri 1 Mlati Kabupaten Sleman Provinsi daerah Istimewa Yogyakarta. Adapun pertimbangan pemilihan sekolah tersebut adalah: (a) di sekolahini merupakansalah satu SMA favorit di Kabupaten Sleman, dan (b) sekolah ini menerapkan pembelajaran sejarah di jurusan IPS dan juga jurusan IPA .

\section{Target/Subjek Penelitian}

Informan kunci dalam penelitian ini adalah Kepala Sekolah SMA Negeri 1 MlatiSleman, Wakil Kepala Sekolah Bidang Kurikulum, Guru Bidang Studi Sejarah, danSiswa Jurusan IPS dan IPA Kelas XI.

\section{Teknik Pengumpulan Data}

Instrumen pengumpulan data adalah suatualat yang digunakan untuk mengukur fenomena alam maupun sosial yang diamati (Sugiyono, 2007: 305). Dalam penelitian kualitatif, yang menjadi instrument utama adalah peneliti itu sendiri. Selain itu, instrumen lainnya yang digunakan dalam penelitian ini adalah pedoman wawancara, lembar observasi dan lembar pencermatan dokumen. Penelitian ini bertujuan untuk mengetahui pembelajaran yang efektif di SMA Negeri 1 Mlati Sleman. Oleh karena itu, instrument penelitian mencakup instrument untuk kepala sekolah, wakil kepala sekolah bidang kurikulum, guru dan siswa. 
(Sugiyono, 2007: 305). Dalam penelitian kualitatif, yang menjadi instrumen utama adalah peneliti itu sendiri. Selain itu, instrumen lainnya yang digunakan dalam penelitian ini adalah pedoman wawancara, lembar observasi dan lembar pencermatan dokumen. Penelitian ini bertujuan untuk mengetahui pembelajaran yang efektif di SMA Negeri 1 Mlati Sleman

Gambar 3.

\section{Analisis Data Kualitatif}

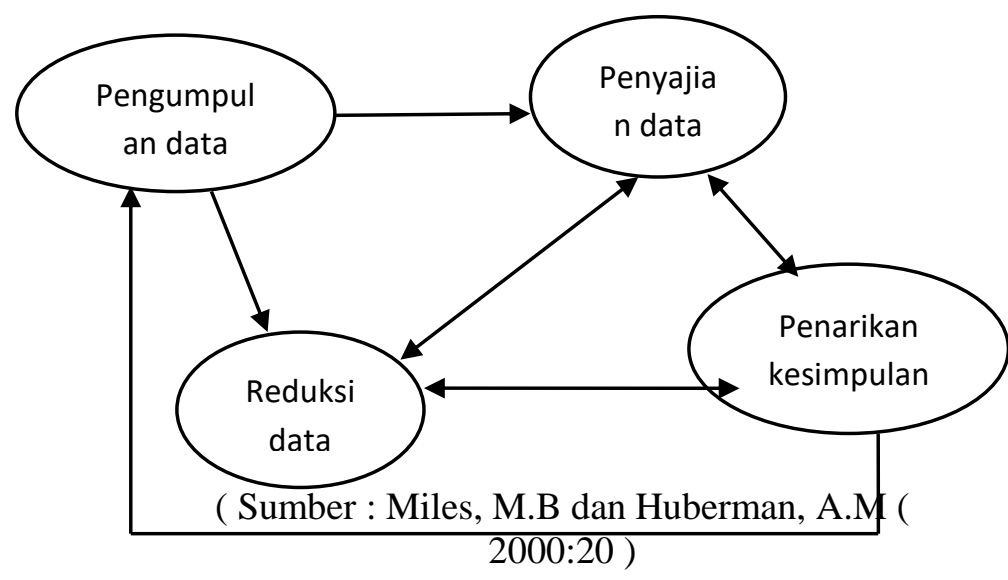

Tahap pengumpulan data dilakukan dengan teknik wawancara, observasi, dan dokumentasi. Data yang diperoleh di lapangan dicatat dalam catatan lapangan berbentuk deskriptif tentang apa yang dilihat, didengar, dirasakan, dan dialami oleh subjek penelitian. Tahap reduksi data meliputi tahap pemilihan, pemusatan, penyederhanaan dan transformasi data kasar yang diperoleh dengan menggunakan catatan lapangan.

Reduksi data dimaksudkan untuk membantu dalam pengklasifikasian aspekaspek penting dari isu yang dikaji. Data reduksi adalah bagian dari analisis, suatu bentuk analisis yang mempertegas, memperpendek, membuatfokus, membuang hal yang tidak penting dan mengatur data sedemikian rupa sehingga kesimpulan akhir dapat dilakukan. Penyajian data merupakan tahap untuk memahami apa yang sedang terjadi dan apa yang harus dilakukan selanjutnya, untuk dianalisis dan diambil tindakan yang dianggap perlu,dan yang terakhir adalah penarikan kesimpulan. Pada tahap ini, peneliti berusaha mencari makna dari komponen-komponen yang disajikan dengan mencatat pola-pola, keteraturan, konfigurasi, hubungan sebab akibat dan proporsi dalam penelitian.

Analisis kualitatif perlu didokumentasikan sebagai suatu proses yang jauh lebih mendalam daripada yang telah dilakukan saat ini. Peneliti memaparkan dalam bentuk naratif berkaitan dengan dimensi kajian utama,yaitu faktor-faktor kunci, atau variabelvariabel, dan hubungan-hubungan antar dimensi melalui jaringan kausal. Menurut Miles dan Huberman (2000: 243) jaringan kausal adalah hubungan visual dari variabelvariabel bergantung dan bebas yang paling penting dalam suatu kajian lapangan dan hubungan-hubungan di antara variable tersebut. Alur hubungan-hubungan ini adalah bersifat sementara dan bukan semata-mata korelasional. Jaringan kausal menjadi berguna dengan mempertautkan teks yang menggambarkan makna hubungan-hubungan antar faktor.

Menggambarkan makna hubunganhubungan antar factor dalam penelitian ini, maka peneliti menggunakan metode fishbone diagram atau tulang ikan/cause and effect (sebab dan akibat). Menurut Eris Kusnadi (2010:1) fishbone diagram akan mengidentifikasi berbagai sebab potensial dari satu efek atau masalah, dan menganalisis masalah tersebut melalui sesi brainstorming. Masalah akan dipecah menjadi sejumlah kategori yang berkaitan, mencakup manusia, material, mesin, prosedur, kebijakan, dan sebagainya. Setiap kategori mempunyai sebabsebab yang perlu diuraikan melalui sesi brainstorming.

Selain itu minat siswa dalam membaca, juga menurunkan minat belajar siswa dalam pembelajaran sejarah. Guru harus membuat kurikulum yang dapat menciptakan materi pembelajaran yang menarik dan tidak membosankan bagi siswa. Hal ini akan berdampak pada siswa menjadi pasif dalam mengikuti pembelajaran sejarah. Minat sangat mempengaruhi dalam proses dan hasil belajar. Kalau siswa tidak berminat untuk mempelajari sesuatu, maka tidak dapat diharapkan akan berhasil dengan baik dalam mempelajari hal tersebut. Begitu pula sebaliknya, jika siswa mempelajari sesuatu dengan minat, maka hasil yang diharapkan akan lebih baik, maka tugas guru adalah untuk dapat menarik minat belajar 
siswa, dengan menggunakan berbagai cara dan usaha mereka.

Guru mempunyai peran dalam pembelajaran sejarah di SMA Negeri 1 Mlati Sleman, dengan upaya memberikan motivasimotivasi kepada siswa untuk lebih semangat dalam belajar.Menjalin komunikasi yang baik antar guru dan siswa. Guru selalu memberikan inspirasi dan dorongan, dan selalu membimbing sikap dan tingkah laku serta nilai-nilai yang baik pada siswa. Guru berupaya menghargai siswa dengan menunjukan minat yang sungguh-sungguh pada pengetahuan dan pengalaman mereka. Seorang guru tidak akan dapat bekerja sama dengan siswa apabila dia tidak ingin memahami atau belajar tentang mereka. Bersikap akrab dan melebur, sehingga siswa tidak merasa kaku dan sungkan dalam berkomunikasi dengan guru.

Belajar merupakan kebutuhan yang penting bagi setiap orang sehingga kata belajar itu sendiri sering kali digunakan dalam kehidupan sehari-hari. Belajar merupakan suatu proses perubahan tingkah laku individual melalui interaksi dengan lingkungan. Lefudin (2017: 2) mengemukakan pengertian belajar sebagai berikut:

Belajar dapat diartikan sebagai proses perubahan perilaku, akibat interaksi individu dengan lingkungan. Perilaku itu mengandung pengertian yang luas. Hal ini mencakup pengetahuan, pemahaman, keterampilan, sikap dan sebagainya. Setiap perilaku ada nampak dan ada pula yang tidak. Perilaku yang nampak disebut penampilan,dan yang tidak bisa diamati disebut kecenderungan perilaku.

Sedangkan Slameto (2005 : 2-4) mendefinisikan belajar yaitu:

1)Belajar merupakan suatu proses usaha yang dilakukan seseorang untuk memperoleh suatu perubahan tingkah laku yang baru secara keseluruhan, sebagai hasil pengalaman sendiri dalam interkasi dengan lingkungannya.

Perubahan tingkah laku dalam pengertian belajar, sebagai perubahan secara sadar. Menyadari pengetahuan bertambahn, kecakapan bertambah, dan kebiasaan bertambah.
2) Perubahan dalam belajar bersifat kontinu dan funsional, berlangsung secara bersinambungan, tidak statis.

3) Perubahan dalam belajar berifat positif dan aktif untuk memperoleh sesuatu yang lebih baik dari sebelumnya.

4)Perubahan dalam belajar bukan bersifat sementara, namun perubahan bersifat menetap atau permanen.

5)Perubahan dalam belajar bertujuan terarah dan perubahan mencakup seluruh aspek tingkah laku.

Menurut FR. Abbat(1998: 10-11) tujuan belajar merupakan pernyataan yang menggambarkan apa yang harus diketahui, dirasakan atau yang seharusnya mampu dikerjakan. Tujuan belajar sangat adalah sangat penting oleh karena mengendalikan keseluruhan proses belajar mengajar. Sementara, tujuan belajar sebagai hasil yang menyertai tujuan belajar instruksional lazim disebut nurturant effects. Bentuknya berupa, kemampuan berpikir kritis, dan kreatif, sikap terbuka dan demokratis, menerima orang lain dan sebagainya. Tujuan ini merupakan konsekuensi logis dari peserta didik "menghidupi" (live in) suatu sistem lingkungan belajar tertentu.

Berdasarkan penjelasan di atas tujuan dari belajar itu sendiri adalah agar peserta didik mempunyai atau mendapatkan pengetahuan dan ketrampilan dalam belajar yang berupa kemampuan berfikir kritis dan kreatif, demokratis dan juga mampu menerima pendapat orang lain atau menghargai orang lain. Dengan begitu akan menciptakan lingkungan belajar yang menyenangkan dan tidak membosankan.

Prestasi adalah hasil yang telah dicapai dari apa yang telah dikerjakan. Prestasi adalah tingkat keberhasilan siswa mencapai tujuan yang telah ditetapkan dalam sebuah program. Lanawati (Winarini Wilman Dahlan Masoer, 2011:168) menjelakasn bahwa prestasi belajar adalah suatu hasil penilaian pendidik terhadap proses belajar dan hasil belajar siswa sesuai dengan tujuan instruksional yang menyangkut isi pelajaran dan perilaku yang diharapkan dari siswa. Pendapat tersebut dapat diartikan bahwa prestasi belajar sebagai nilai yang merupakan bentuk rumusan akhir yang diberikan guru 
terkait dengan kemajuan atau prestasi belajar siswa selama waktu tertentu.

Berdasarkan pendapat di atas dapat disimpulkan bahwa prestasi belajar adalah hasil yang dicapai siswa dalam belajarnya yang meliputi kemampuan penguasaan, pengetahuan dan ketrampilan yang telah diajarkan di sekolah. Dengan melihat hasil dari tes formatif, tes sumatif nilai rapor maka dapat dilihat sejauh mana prestasi belajar yang telah dicapai oleh siswa. Prestasi belajar yang diperoleh merupakan suatu hasil dari perubahan karena belajar.Prestasi belajar sebagai tingkat keberhasilan siswa mencapai tujuan yang telah ditetapkan setelah melakukan proses belajar lazimnya ditunjukkan dengan nilai tes atau angka nilai yang diberikan oleh guru.

Prestasi belajar pada dasarnya adalah hasil akhir yang diharapkan dapat dicapai setelah seseorang belajar. Menurut Ahmad Tafsir (Marlina, 2011;4), hasil belajar atau bentuk perubahan tingkah laku yang diharapkan itu merupakan suatu target atau tujuan pembelajaran yang meliputi 3 (tiga) aspek yaitu: 1) tahu, mengetahui (knowing); 2) terampil melaksanakan atau mengerjakan yang ia ketahui itu (doing); dan 3) melaksanakan yang ia ketahui itu secara rutin dan konsekuen (being). Menurut Bloom, sebagaimana yang dikutip oleh Hunt, Carper, Lasley, dan Raisch (210: 107) bahwa hasil belajar diklasifikasikan ke dalam tiga ranah yaitu: 1) ranah kognitif(cognitive domain);2) ranah afektif(affective domain); dan 3) ranah psikomotor (psychomotor domain).

Berdasarkan hal tersebut, maka peneliti berkesimpulan bahwa jenis prestasi belajar itu meliputi 3 (tiga) ranah, yaitu: 1) ranah kognitif (cognitive domain);2) ranah afektif (affective domain); dan 3) ranah psikomotor (psychomotor domain). Untuk mengungkap hasil belajar atau prestasi belajar pada ketiga ranahdi atas diperlukan indikatorindikator sebagai penunjuk bahwa seseorang telah berhasil meraih prestasi pada tingkat tertentu dari ketiga ranah tersebut. Dalam hal ini Bloom lebih menekankan (Darmadi, 2017:24) perhatiannya pada apa yang mesti dikuasi oleh individu (sebagai tujuan belajar. Oleh karena itu memperoleh ukuran dan data hasil belajar siswa sebagaimana yang terurai di atas adalah mengetahui garis-garis besar indikator (penunjuk adanya prestasi tertentu) dikaitkan dengan jenis prestasi yang hendak diungkapkan atau diukur.

Berdasarkan uraian di atas, bahwa pengetahuan dan pemahaman yang mendalam mengenai indikator-indikator prestasi belajar sangat diperlukan ketika seseorang akan menggunakan alat dan kiat evaluasi. Urgensi pengetahuan dan pemahaman yang mendalam mengenai jenis-jenis prestasi belajar dan indikator-indikatornya adalah bahwa pemilihan dan pengunaan alat evaluasi akan menjadi lebih tepat, reliabel, dan valid.

Dalam perencanaan pengajaran yang tertuang dalam satuan pelajaran, sebgaimana dijelaskan oleh Syaifudin Sagala (2006: 179) bahwa evaluasi selalu memegang peranan penting dalam segala bentuk pengajaran. Dengan evaluasi diperoleh feedback yang dipakai untuk memperbaiki dan merevisi bahan atau metode pengajaran atau untuk menyesuaikan bahan dengan perkembangan ilmu pengetahuan. Hal tersebut dapat dikatakan bahwa cara pengukuran prestasi belajar berkaitan dengan evaluasi, dimana dalam dunia pendidikan lebih dikenal dengan tes, ujian, dan ulangan. Muhibbin Syah (Nurbitullah, 2014:2-3) mengatakan pada prinsipnya, evaluasi hasil belajar merupakan kegiatan berencana dan berkesinambungan. Oleh karena itu, ragamnya pun juga banyak, mulai yang paling sederhana sampai yang paling kompleks. Berikut dijelaskan beberapa ragam evaluasi, yaitu:

1)Pre-test dan post test

Kegiatan pre test dilakukan guru secara rutin pada setiap akan memulai penyajian materi baru. Sedangkan post test yaitu kegiatan evaluasi yang dilakukan guru pada setiap akhir penyajian materi.

2)Evaluasi prasyarat

Evaluasi jenis ini sangat mirip dengan pre test. Tujuan untuk mengidentifikasi penguasaan siswa atas materi lama yang mendasari materi baru yang akan disajikan.

3)Evaluasi Diagnostik

Evaluasi ini dilakukan setelah selesai penyajian sebuah satuan pelajaran, dengan tujuan mengidentifikasi bagian-bagian tertentu yang belum dikuasai siswa.Instrumen evaluasi jenis ini dititikberatkan pada bahasan tertentu yang dipandang telah membuat siswa mendapatkan kesulitan. 


\section{4)Evaluasi Formatif}

Evaluasi jenis ini kurang lebih sama dengan ulangan yang dilakukan pada setiap akhir penyajian satuan pelajaran atau modul.Menurut Syaifudin Azwar (1998:11) menjelaskan penilaian formatif untuk digunakan hasil tes prestasi belajar dapat melihat sejauhmana kemajuan belajar yang telah dicapai oleh siswa dalam suatu program pelajaran.

5)Evaluasi Sumatif

Penilaian sumatif kurang lebih sama dengan ulangan umum yang dilakukan untuk mengukur prestasi belajar siswa pada akhir periode pelaksanaan program pengajaran. Hasilnya dijadikan bahan laporan resmi mengenai prestasi belajar siswa dan bahan penentu naik atau tidaknya siswa ke kelas yang lebih tinggi.

6)UAN

Ujian Akhir Nasional (UAN) pada prinsipnya sama dengan evaluasi sumatif dalam arti sebagai alat penentu kenaikan status siswa. Mengatakan langkah pertama yang perlu ditempuh Guru dalam menilai prestasi belajar siswa adalah menyusun alat evaluasi yang sesuai dengan kebutuhan, dalam arti tidak menyimpang dari indikator dan jenis prestasi yang diharapkan.

Secara garis besar, Thursan Hakim (2010: 11) faktor yang mempengaruhi prestasi belajar anak atau individu dapat dibagi dalam dua bagian, diantaranya:

1)Faktor internal merupakan faktor yang berasal dari dalam diri individu. Faktor internal terdiri dair faktor biologis dan faktor psikologis.

2)Faktor eksternal merupakan faktor yang bersumber dari luar indivndu itu sendiri. Faktor ekternal meliputi faktor lingkungan keluarga, faktor lingkungan sekolah, faktor lingkungan masyarakat, faktor waktu.

Berhasil atau tidaknya seseorang dalam belajar disebabkan beberapa faktor yang mempengaruhi pencapaian hasil belajar. Pencapaian hasil belajar itu berasal dari faktor yang ada dalam diri dan yang ada di luar orang itu sendiri. Lebih lanjut Thursan Hakim (2010: 11-17) faktor-faktor yang menentukan pencapaian hasil belajar sebagai berikut: 1)Faktor internal (yang berasal dari dalam diri) a) Faktor jasmani yang bersifat bawaan maupun yang diperoleh, yaitu panca indra yang tidak berfungsi sebagaimana mestinya seperti mengalami sakit cacat tubuh atau perkembangan tidak sempurna.

b) Faktor psikologis baik bersifat bawaan maupun diperoleh yaitu sebagai berikut:

(1)Faktor intelektif yang meliputi faktor potensial yaitu kecerdasan dan bakat serta faktor kecakapan nyata yaitu prestasi yang dimiliki.

(2)Faktor intelektif yaitu unsur-unsur kepribadian tertentu seperti sikap, kebiasaan, minat, kebutuhan, motivasi, emosi, dan penyesuaian diri.

c)Faktor kamatangan fisik maupun psikis

1)Faktor eksternal (yang berasal dari luar diri). (a)Faktor sosial yang terdiri dari lingkungan keluarga, lingkungan sekolah, masyarakat, dan lingkungan kelompok.

(b)Faktor budaya seperti adat istiadat, ilmu pengetahuan, teknologi, dan kesenian.

(c)Faktor lingkungan fisik seperti fasilitas rumah dan fasilitas belajar.

(d)Faktor lingkungan spirirtual dan keagamaan.

Berdasarkan dari pernyataan di atas pencapaian hasil belajar dipengaruhi oleh berbagai faktor, yaitu faktor yang berasal dari dalam diri orang itu sendiri dan di luar diri orang itu sendiri.

Pembelajaran merupakan perilaku yang hendak dicapai yang dapat dikerjakan oleh siswa pada kondisi dan tingkat kompetensi tertentu. Menurut Nana Syaodih Sukmadinata (2014:131) kegiatan belajar mengajar tidak dapat dilepaskan dari belajar, sebab keduanya merupakan dua sisi dari sebuah mata uang. Mengajar merupakan suatu upaya yang idlakukan guru agar siswa belajar. Syaiful Vahri dan Aswan Zain menjelaskan bahwa (2006:37) kegiatan belajar mengajar adalah suatu kondisi yang dengan sengaja diciptakan oleh guru dengan tujuan membelajarkan siswa, dimana guru sebagai pelajar dan siswa sebagai anak didik. Kesatuan atau perpaduan kedua unsur ini maka lahirlah interkasi yang edukatif dengan memanfaatkan bahan sebagai mediumnya.

Pembelajaran merupakan kegiatan belajar mengajar. Pembelajaran merupakan suatu 
prose yang dilakukan oleh individu untuk memperoleh suatu perubahan perilaku yang baru secara keseluruhan, sebagai hasil dari pengalaman individu itu sendiri dalam interaksi dengan lingkungannya. Menurut Rochmat Wahab (2009: 4) pembelajaran orang dewasa memang mendorong peserta didik untuk terlibat pada persoalan dunia riil dan mengaitkan belajar dengan kebutuhan atau tujuannya, serta mengaitkan materi belajar dengan masa lalunya, sehingga peserta didik benar-benar merasakan asyik dalam belajar. Dalam situasi yang begini, peserta didik sungguh menjadi sumber utama proses pembelajaran.

Pembelajaran pada hakikatnya tidak hanya sekedar menyampaikan pesan pembelajaran kepada siswa, akan tetapi merupakan aktivitas profesional yang menuntut guru untuk dapat menggunakan keterampilan dasar mengajar secara Tematik, serta menciptakan sistem lingkungan yang memungkinkan siswa dapat belajar secara efektif dan efisien. Proses belajar yang disertai dengan pembelajaran akan lebih efektif dan terarah daripada belajar dari pengalaman dalam kehidupan sosial. Agar pembelajaran lebih terarah proses pembelajaran terdiri dari beberapa komponen yang harus saling berinteraksi. Komponen tersebut adalah tujuan pembelajaran, materi pembelajaran, metode, model, strategi pembelajaran, media dan evaluasi.

Belajar aktif yang dikemukakan oleh Slameto (2005: 27), dalam belajar setiap harus disuahakan pertisipasi aktif, meningkatkan minat dan membimbing untuk mencapai tujuan instruksional. Sebagaimana siswa SMA merupakan pembelajar yang dalam pelaksanaannya menyesuaikan dengan cara belajar orang dewasa. Seperti ditegaskan oleh Baim (2016: 1) bahwa adult learners show tremendous diversity in their backgrounds, approach learning in a myriad of differ-ent ways, and rely heavily on their past experiences to help guide their future knowledge acquisition. Artinya Peserta didik dewasa menunjukkan keragaman yang luar biasa dalam latar belakang mereka, mendekati pembelajaran dengan berbagai cara yang berbeda, dan sangat bergantung pada pengalaman masa lalu mereka untuk membantu memandu pengetahuan masa depan mereka.

Silberman (Winastwan Gora dan Sunarto, 2007: 10) menggambarkan saat belajar aktif, para siswa melakukan banyak kegiatan. Siswa menggunakan otak untuk mempelajarai ideide, memecahkan permasalahan, dan menerapkan apa yang meraka pelajari. Asas aktivitas dapat diterapkan dalam semua kegiatan dan proses pembelajaran. Untuk memudahkan guru dalam melaksanakan asas ini, maka dalam hal ini dipilih empat alternatif pendayagunaan saja, yakni:

1)Pelaksanaan aktivitas pembelajaran dalam kelas.

Asas aktivitas dapat dilaksanakan dalam setiap tatap muka dalam kelas yang terstruktur, baik dalam bentuk komunikasi langsung, kegiatan kelompok, kegiatan kelompok kecil, belajar independen.

2) Pelaksanaan aktivitas pembelajaran sekolah masyarakat.

Dalam pelaksanaan pembelajaran dilakukan dalam bentuk membawa kelas kedalam masyarakat, melalui metode karya wisata, survei, keja lapangan, pelayanan masyarakat, dan sebagainya. Cara lain, mengundang nara sumber dari masyarakat ke dalam kelas, dan pelatihan di luar.

3) Pelaksanaan aktivitas pembelajaran dengan pendekatan PAKEM (Pembelajaran Aktif Kreatif dan Menyenangkan).

Pembelajaran dititik beratkan pada keaktifan siswa dan guru bertindak sebagai fasilitator dan nara sumber, yang memberikan kemudahan bagi siswa untuk belajar.

Upaya melaksanakan pembeljaran yang menekankan pada pengaktifan belajar siswa didasarkan atas asumsi-asumsi tertentu. Ada sejumlah asumsi dasar pembelajaran yang berpusat pada siswa (Sumiati dan Asra, 2009: 39-40) sebagai berikut: (1) kegiatan belajar merupakan proses kotinyu dan bervariasi, (2) dalam proses belajar ada keterlibatan mental daris siswa secara optimal, (3) komunikasi dalam pembelajaran berlangsung dalam banyak arah, dan (4) untuk mengarahkan kegiatan belajar siswa, perlu menggunakan berbagai metode pembelajaran yang efektif.

Berkaitan dengan meningkatkan aktivitas belajarsiswa, seperti ditegaskan Bender dan Hill (2016: 97) in an effort to provide stu-dents with the most robust learning experience 
possible, teacher should create a blended learning environment that addresses multiple learning styles; thus engaging stu-dents into a dynamic learning process. Artinya dalam upaya untuk menyediakan siswa dengan pengalaman belajar yang paling kuat, guru harus menciptakan lingkungan belajar campuran yang membahas banyak gaya belajar; sehingga melibatkan siswa dalam proses belajar yang dinamis.

Menurut Joh Holt (Silberman, 2012: 20) proses belajar akan meningkat jika siswa diminta untuk melakukan hal-hal, di antaranya: (1) mengemukakan kembali informasi dengan kata-kata, (2) memberikan contohnya, (3) mengenali dalam bermacam bentuk, (4) melihat kaitan antara informasi dengan fakta, (5) menggunakan dengan beragam cara, (6) memrediksikan sejumlah konsekuensi, dan (7) menyebutkan lawan atau kebalikannya. Aktivitas siswa dalam pembelajaran mempunyai peranan yang sangat penting. Aktivitas dalam proses belajar mengajar merupakan rangkaian kegiatan yang meliputi keaktifan siswa dalam mengikuti pelajaran, bertanya hal yang belum jelas, mencatat, mendengar, berfikir, membaca, dan segala kegiatan yang dilakukan yang dapat menunjang prestasi belajar.

Pembelajaran Sejarah yang efektif di SMA Negeri 1 Mlati Sleman, Display data dapat dibuat fishbone diagram, sebagai berikut:

Gambar 4

Fishbone Diagram pembelajaran Sejarah yang

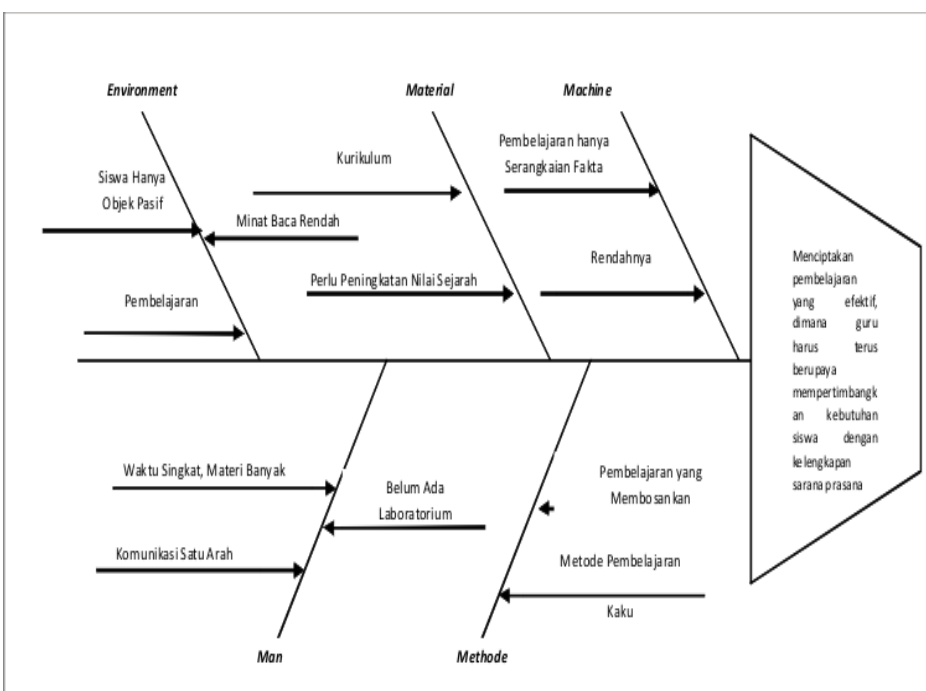

Hasil diagram fishbone menunjukkan bahwa pembelajaran sejarahdi SMA Negeri Mlati 1 Sleman, apabila guru dalamhal ini belum mampu menerapkan metode, model dan evaluasi yang baik maka pembelajaran yang efektif tidak akan tercapai serta tidak terjadi interaksi dan komunikasi dua arah dalam pembelajaran. Metode merupakan upaya untuk mengimplementasikan rencana yang sudah disusun dalam kegiatan nyata agar tujuan yang telah disusun tercapai secara optimal.Metode digunakan untuk merealisasikan strategi yang telah ditetapkan. Strategi menunjuk pada sebuah perencanaan untuk mencapai sesuatu, sedangkan metode adalah cara yang dapat digunakan untuk melaksanakan strategi. Dengan demikian suatu strategi dapat dilaksanakan dengan berbagai metode.

Kaidah yang berlaku dalam penerapan standar, pembelajaran dinyatakan efektif jika menggunakan metode yang bervariasi. Hal ini memang beresiko karena perlu ada sistem penjaminan bahwa kebervariasian menggunakan metode itu benar-benar mengarah pada pencapaian tujuan.Jika tidak maka kebervariasian itu tidak menjamin berkembangnya motivasi dan minat siswa belajar. Jika kebervariasian metode mengajar menjadi ciri efektifnya guru mengajar, maka guru yang profesional harus ditandai dengan menguasai sejumlah metode dan mampu mengaplikasikannya .Pekerjaan itu dinyatakan efektif jika benar-benar memfasilitasi siswa belajar untuk menguasai kompetensi yang diharapkan.

Kenyataan yang ada pada saat ini bahwa dalam komunikasi sering terjadi penyimpangan, sehinggaproses belajar mengajar menjadi tidak efektif dan efisien. Keadaan tersebutdisebabkan oleh beberapa hal diantaranya: ada kecenderungan verbalisme,ketidaksiapan peserta didik, kurang minat peserta didik, kurangnya sarana danprasarana pembelajaran.Selain itu proses belajar mengajartidak efektif dikarenakan, sebagian guru belum sepenuhnya menerapkan model-model pembelajaran misalnya model pembelajaran kontesktual dalam proses pembelajaran,kegiatan belajar mengajar yang dilakukan kurang menarik, berlangsung monotondan membosankan, serta interaksi 
yang terjadi hanya satu arah karena guru yang dominan aktif.

Selain itu minat siswa dalam membaca, juga menurunkan minat belajar siswa dalam pembelajaran sejarah. Guru harus membuat kurikulum yang dapat menciptakan materi pembelajaran yang menarik dan tidak membosankan bagi siswa. Hal ini akan berdampak pada siswa menjadi pasif dalam mengikuti pembelajaran sejarah. Minat sangat mempengaruhi dalam proses dan hasil belajar. Kalau siswa tidak berminat untuk mempelajari sesuatu, maka tidak dapat diharapkan akan berhasil dengan baik dalam mempelajari hal tersebut. Begitu pula sebaliknya, jika siswa mempelajari sesuatu dengan minat, maka hasil yang diharapkan akan lebih baik, maka tugas guru adalah untuk dapat menarik minat belajar siswa, dengan menggunakan berbagai cara dan usaha mereka.

Kemampuan kognitif yang paling utama adalah kemampuan seseorang dalam melakukan persepsi, mengingat, dan berpikir. Setelah diketahui berbagai faktor yang mempengaruhi proses dan hasil belajar seperti diuraikan di atas, maka hal penting yang harus dilakukan bagi guru, adalah mengatur faktorfaktor tersebut agar dapat berjalan seoptimal mungkin. Walaupun diakui bahwa tujuan pendidikan yang berarti juga tujuan belajar itu meliputi tiga aspek, yaitu aspek kognitif, aspek afektif, dan aspek psikomotorik.Namun tidak dapat diingkari, bahwa sampai sekarang pengukuran kognitif masih diutamakan untuk menentukan keberhasilan belajar seseorang.Sedangkan aspek afektif dan aspek psikomotorik lebih bersifat pelengkap dalam menentukan derajat keberhasilan belajar siswa di sekolah. Oleh karena itu, kemampuan kognitif akan tetap merupakan faktor penting dalam belajar siswa.

Untuk mencapai secara optimal pembelajaran yang efektif di SMA Negeri 1 Mlati Sleman, maka pentingnya guru memperhatikan faktor-faktor yang mempengaruhi belajar pada siswa yang mencakup metode mengajar, kurikulum, relasi guru dengan siswa, relasi siswa dengan siswa, disiplin sekolah, pelajaran dan waktu sekolah, standar pelajaran, laborotorium sejarah, metode belajar dan tugas rumah seperti telah disebutkan di atas. Agar para siswa belajar dengan baik dalam pembelajaran sejarah, maka metode harus diusahakan yang setempat yang tepat, efesien dan para guru yang aktif dan berani mengembangkan metode yang baru, yang dapat meningkatkan metode kegiatan belajar mengajar dan meningkatkan motivasi untuk belajar siswa dalam pembelajaran sejarah.

Selain itu, kurikulum dalam pembelajaran sejarah perlu mendapat perhatian bagi pihak sekolah. Kegiatan ini sebagai besar adalah menyajikan bahan belajaran agar para siswa menerima, mengusai dan mengembangkan pelajara sejarah tersebut.Jelaslah bahan pelajaran itu mempengaruhi belajar siswa, kulikulum yang kurang baik berpengaruh tidak baik terhadap belajar. Perlu diingat bahwa sistem instruksional sekarang mengaruhi proses belajar mengajar yang memetingan kebutuhan siswa, guru perlu mendalam, siswa dengan baik, harus mempunyai perencaan yang mendetail, agar dapat melayani siswa belajar secara indiviual. Kurikulum ini tentunya perlu didukung oleh kedisplinan sekolah, baik siswa maupun guru.

Kedisiplinan sekolah erat hubungannya dengan kerajinan siswa dalam sekolah dan juga dalam belajar.Kedisiplinan sekolah mencakup kedisiplinan guru dalam mengajar dengan melaksanakan tata tertib, kedisiplinan guru dalam pekerjaan administrasi dan kebersihan/keteraturan kelas, gedung sekolah dan lain-lain.Dengan demikian agar siswa belajar lebih maju, siswa harus disiplin di dalam belajar baik di sekolah, di rumah dan di perpustakaan, agar siswa disiplin haruslah guru beserta staf yang lain disiplin.

Faktor yang mempengaruhi seseorang dalam belajar itu banyak jenisnya. Faktorfaktor belajar itupun dibagi menjadi dua bagian yaitu faktor intern yang berasal dari dalam dan faktor ekstern atau berasal dari luar.faktor luar banyak dipengaruhi dari dalam diri siswa itu sendiri dan faktor eksternal dipengaruhi oleh lingkungan luar.Faktor internal yaitu faktor faktor yang berasal dari seseorang sendiri dan dapat mempengaruhi terhadap belajarnya.Faktor internal dibedakan menjadi 
tiga yaitu faktor jasmaniah, faktor kelelahan dan faktor psikologi.Faktor eksternal yaitu faktor faktor yang berasal dari lingkungan luar dan dapat mempengaruhi terhadap belajarnya.Faktor eksternal dibedakan menjadi tiga yaitu faktor keluarga, faktor sekolah dan faktor masyarakat.

Dalam kegiatan belajar, sering timbul permasalahn atau hambatan pada anak. Permasalahan belajar dapat timbul dari dalam diri anak (internal) maupun dari luar (eksternal). Hambatan internal meliputi fisiologis, biologis dan psikologis anak., mulai dari kecerdasan, motivasi, minat sampai bakat siswa. Sedangkan hambatan eksternal meliputi lingkungan sosial maupun lingkungan nonsosial. Untuk mencapai hasil belajar yang maksimal, hambatan belajar tersebut harus dibatasi. Berbagai hambatan yang timbul saat belajar dapat di atasi mulai dari diri anak sendiri, keluarga, sekolah maupun lingkungan masyarakat.

Eddy Lion (2015: 4) menegaskan bahwa guru yang kompeten akan lebih mampu menciptakan lingkungan belajar yang efektif dan akan lebih mampu mengelola kelasnya sehingga hasil belajar siswa berada pada lingkungan tingkat optimal. Salah satu strategi pembelajaran yang berpusat pada siswa yaitu Pembelajaran Berbasis Masalah (PBM). Menurut Barrow (Dindin Abdul Muiz

Pembelajaran sejarah yang dilakukan di SMA Negeri 1 Mlati Sleman saati ini mampu mengadopsi model pembelajaran Dick and Carey, walaupun belum secara optimal dipraktekkan.Pembelajaran sejarah di SMA Negeri 1 Mlati Sleman sudah melakukan tahapan di antaranya, merancang tujuan pembelajaran, menganalisis materi sesuai dengan tujuan pembelajaran, analisis kompetensi awal dan karakteristik siswa, analisis buku panudan dalam pembelajran, merancang metode pengajaran, merancang media pengajaran, dan evaluasi hasil belajarn dan sistem pengajaran.

Model pembelajaran Dick dan Carey merupakan model pembelajaran yang dikembangkan melalui pendekatan sistem (system approach).Terhadap komponenkomponen dasar dari desain sistem pembelajaran yang meliputi analisis, desain, pengembangan, implementasi dan evaluasi. Model sistem pembelajaran yang dikembangkan oleh Dick and Carey terdiri atas beberapa komponen yang perlu dilakukan untuk membuat rancangan aktivitas pembelajaran yang lebih besar. Dick dan Carey memasukan unsur kognitif dan behavioristik yang menekankan pada respon siswa terhadap stimulus yang dihadirkan.Implementasi model desain sistem pembelajaran ini memerlukan proses yang sistematis yang menyeluruh. Hal ini diperlukan untuk dapat menciptakan desain sistem pembelajaran yang mampu digunakan secara optimal dalam mengatasi masalahmasalah pembelajaran.

\section{Hasil Penelitian dan Pembahasan}

Berdasarkan uraian hasil penelitian dan pembahasan, dapat disimpulkan sebagai berikut:

Pembelajaran sejarah di SMA Negeri 1 Mlati Sleman, merupakankegiatan belajar mengajar yang didalam terdapat kegiatan memilih, menetapkan, mengembangkan metode untuk mencapai hasil pengajaran yang diinginkan. Pemilihan, penetapan, dan pengembangan metode ini didasarkan pada kondisi pengajaran yang ada khususnya pada pembelajaran sejarah. Dalam pembelajaran sejarah yang efektif, guru berupaya mempertimbangkan kebutuhan siswa dengan kelengkapan sarana dan prasarana yang ada di sekolah. Guru juga berupaya selama KBM harus memberdayakan seluruh potensi sehingga sebagian besar siswa diharapkan mampu mencapai kompetensi individual yang diperlukan unuk mengikuti pelajaran sejarah.

Penggunaan model pembelajaran sejarah di SMA Negeri 1 Mlati Sleman, merupakan strategi pembelajaran dala upaya meningkatkan minat belajar siswa dalam pelajaran sejarah. Salah satu model pembelajaran sejarah yang digunakan adalah gambar maupun video yang dilakukan agar gambar dapat diurutkan menjadi urutan logis. Salah satu model pembelajaran dalam pembelajaran sejarah yang sudah di terapkan terapkan adalah model pembelajaran kooperatif. Dimana dalam model pembelajaran 
ini guru membagikan materi pada tiap siswa untuk dibaca dan membuat ringkasan. Model ini membantu mengingat atau menghafal ideide pokok dengan menghubungkan materi sebelumnya atau dengan materi lainnya.

Evaluasi pembelajaran di SMA Negeri 1 Mlati Sleman sudah dipersiapkan pada awal atau waktu pembuatan program semester kecuali untuk evaluasi atau ujian akhir sekolah direncanakan atau diambil waktu persiapan evaluasi harian dari setiap sub pokok bahasan. Untuk evaluasi ada tes tulis, tes lisan (tanya jawab). Untuk instrumen penilaiannya tercantum penilaian afektif dan psikomotorik. Bentuk evaluasi lainnya, yaitu ulangan harian, mid semester dan ujian akhir semester.

Dalam pembelajaran sejarah di SMA Negeri 1 Mlati Sleman ada berbagai faktor yang mempengaruhi efektivitas pembelajaran, baik dari faktor guru, faktor siswa, materi pembelajaran, media, metode maupun model pembelajaran. Faktor yang mendukung pembelajaran, yaitu strategi pembelajaran agar materi yang disampaikan dapat diterima dengan baik oleh siswa dan menumbuhkan minat belajar siswa, karena minat sangat mempengaruhi dalam proses dan hasil belajar.

Faktor yang menghambat pembelajaran sejarah di antaranya kemampuan siswa yang berbeda-beda sehingga dibutuhkan pendekatan pembelajaran secara individu kepada setiap siswa. Hambatan lain berupa sumber dan alat-alat pembelajaran seperti laboratorium sejarah yang belum dimiliki SMA Negeri 1 Mlati Sleman.

Peran guru dalam pembelajaran sejarah di SMA Negeri 1 Mlati Sleman, dengan upaya memberikan motivasi-motivasi kepada siswa untuk lebih semangat dalam belajar. Menjalin komunikasi yang baik antar guru dan siswa. Guru selalu memberikan inspirasi dan dorongan, dan selalu membimbing sikap dan tingkah laku serta nilai-nilai yang baik pada siswa. Guru berupaya menghargai siswa dengan menunjukan minat yang sungguhsungguh pada pengetahuan dan pengalaman mereka. Seorang guru tidak akan dapat bekerja sama dengan siswa apabila dia tidak ingin memahami atau belajar tentang mereka. Tingkat penyerapan siswa dalam pembelajaran sejarah di SMA Negeri 1 Mlati Sleman, sangat berkaitan dengan pemahaman siswa. Dalam proses pembelajaran, setiap individu siswa memiliki kemampuan yang berbeda-beda dalam memahami apa yang dipelajari. Ada yang mampu memahami materi secara menyeluruh dan ada pula yang sama sekali tidak dapat mengambil makna dari apa yang telah dia pelajari, sehingga yang dicapai hanya sebatas mengetahui.

\section{Simpulan}

Peran utama dalam pengajaran adalah menciptakan model aktivitas pengajaran kuat dan tangguh.Intinya adalah aktivitas pengajaran sebagai penataan lingkungan, pengaturan ruang kelas, yang didalamnya para pelajar dapat berinterkasi dan belajar mengetahui bagaimana caranya belajar.Berkaitan dengan efektivitas pengajaran, untuk mencapai pembelajaran aktif, satu aspek penting adalah masalah metode yang digunakan guru dalam menciptakan suasana aktif. Muara dari berfungsinya manajemen pembelajaran yang baik adalah pembelajaran efektif. Artinya, dari posisi guru tercipta mengajar efektif, dari posisi murid tercipta belajar efektif. Guru yang berhasil adalah mengajar murid bagaimana memiliki informasi dalam pembicaraan dan membuatnya menjadi milik mereka.Sedangkan pelajar efektif adalah membentuk informasi, gagasan dan kebijaksanaan dari guru mereka dan menggunakan sumber daya belajar secara efektif.

Pembelajaran efektif akan melatih dan menanamkan sikap demokratis bagi siswa. pembelajaran efektif juga dapat menciptakan suasana pembelajaran yang menyenangkan sehingga memberikan kreatifitas siswa untuk mampu belajar dengan potensi yang sudah mereka miliki yaitu dengan memberikan kebebasan dalam melaksanakan pembelajaran dengan cara belajarnya sendiri. Di dalam menempuh dan mewujudkan tujuan pembelajaran yang efektif maka perlu dilakukan sebuah cara agar proses pembelajaran yang diinginkan tercapai yaitu dengan cara belajar efektif. Untuk meningkatkan cara belajar yang efektif perlu adanya bimbingan dari guru.

\section{Saran}

Berdasarkan uraian kesimpulan dan impilkasi penelitian, maka dapat diajukan saran sebagai berikut: 
Pihak sekolah menerapkan cara belajar dan efisien bagi siswa dengan mengoptimalkan model pembelajaran Dick and Carey, yang memungkinan pemahaman terhadap suatu materi pelajaran yang lebih baik, sehingga pembelajaran bisa lebih variatif dan tidak monoton.Selain itu, penggunaan model Dick dan Carrey pada awal proses pembelajaran, siswa dap dalam pengembangan suatu mata pelajaran dimaksudkan agar pada awal proses pembelajaran, siswa dapat mengetahui dan mampu melakukan hal-hal yang berkaitan dengan materi pada akhir pembelajaran.

Perlunya kebervariasian metode mengajar yang menjadi ciri efektifnya guru mengajar, karena guru yang profesional harus ditandai dengan menguasai sejumlah metode dan mampu mengaplikasikannya. Pembelajaran dinyatakan efektif jika benarbenar memfasilitasi siswa belajar untuk menguasai kompetensi yang diharapkan.

Belajar efektif dan efisien merupakan hal yang harus dilakukan dan dicoba oleh siswa. Belajar tidak hanya dilakukan di sekolah, tetapi juga diulang pembelajarannya di rumah secara individu atau kelompok.Belajar secara efektif dan efisien termasuk memerlukan waktu yang panjang dan suasana tenang juga suasa gembira, dan menyenangkan.

\section{DAFTAR PUSTAKA}

Ahmad Baedowi, dkk. (2015). Manajemen sekolah yang efektif. Jakarta: Pustaka Alvabet.

Asep Jihad dan Abdul Haris. (2010). Evaluasi pembelajaran. Yogyakarta: Multi Presindo.

Azhar Arsyad. (2011). Media pembelajaran. Jakarta: PT. Raja Grafindo Persada.

Baim, Susan A. (2016). The Knowledge Cafe: A Unique Teaching Experience. The Journal of Effective Teaching, Vol. 16, No.3, 2016, 85-106.

Bender, Sara dan Hill, Karlie.(2016). Pedagogical Considerations for Effectively Teaching Qualitative Research to Students in an Online
Environment.The Journal of Effective Teaching, Vol. 16, No.2, 2016, 93-103.

Darmadi. (2017). Pengembangan model metode pembelajaran dalam dinamika belajar siswa. Yogyakarta: Penerbit Deepublish.

Didin Abdul Muiz Lidinillah. (2015). Pembelajaran berbasis masalah. Bandung: Direktor File UPI.

Eddy Lion. (2015). Kemampuan profesional guru dalam pembelajaran efektif. Jurnal Pendidikan Volume 3 Nomor 1 ISSN 2355-0236.

Eris Kusnadi. (2010). Fishbone diagram danlangkah-langkah pembuatannya. Diakses melalui: https://eriskusnadi.wordpress.com/2011 /12/24/fishbone-diagram-dan-langkahlangkah-pembuatannya/padatanggal 11 Maret 2017 pukul 09.35.

ErlinaWiyanarti. (2010). Model pembelajaran kontekstual dalam pengembangan pembelajaran sejarah. Bandung: UPI.

FR. Abbat. (1998). Teaching for better learning (Pengajaran efektif). Terjemahan: dr. Ali Ghufron Mukti. Jakarta: Penerbit Buku Kedokteran EGC.

KBBI.(2017). Pengertian Aktivitas. Diakses melalui:

https://kbbi.web.id/aktivitaspadatanggal 10 Maret 2017 Pukul 11.25 WIB.

Lefudin. (2017). Belajar dan pembelajaran Yogyakarta: Penerbit Deepublihs.

Marlina.(2011). Indikator prestasi belajar. Diakses melalui: https://marlina2.wordpress.com/2011/0 3/31/indikator-prestasi-belajar/, pada tangagl 3 Maret 2017 pukul 09.55 WIB

Masrinawatie. (2008). Hal-hal yang harus diperhatikan dalam Melaksanakan Pembelajaran.Jakarta:Konsorsium Program PJJ S1 PGSD. 
Miles, M. B dan Huberman, A.M (2010). Kualitative Data Analysis. London: Sage Publications.

Marlina.(2011). Indikator prestasi belajar. Diakses melalui: https://marlina2.wordpress.com/2011/0 3/31/indikator-prestasi-belajar/, pada tangagl 3 Maret 2017 pukul 09.55 WIB

Nana Syaodih Sukmadinata. (2014). Pengembangan kurikulum. Teori dan praktik. Bandung:PT Remaja Rosakarya.

Ravi, V. (2010).Educational technology.New Jersey: Pearson Education.

Riduwan. (2010). Manajemen Pendidikan. Bandung : Alfabeta.

Rochmat Wahab. (2009). Pembelajaran yang efektif, efisien, dan menarik sesuai dengan perkembangan teknologi modern. Makalah dalam Seminar Pendidikan Pemanfaatan Teknologi Modern guna Meningkatkan Kemampuan Pendidik Akademi Angkatan Udara Yogyakarta, 24 Juni 2009 di Kampus AAU Yogyakarta.

Salehu ddin Yasin. (2012). Metode belajar dan pembelajaran yang efektif. Jurnal Adabiyah, ISSN: 1421-6141 Vol. XII No. I/2012.

Silviany Ayu Siti Fatimah. (2010). Pengembangan media slide pembelajaran sejarah dan quiz team pada materi pergerakan kebangsaan Indonesia untuk meningkatkan motivasi dan hasil belajar siswakelas VIII SMPN 21 malang. JurnalPenelitian. Malang: Universitas Negeri Malang.

Slameto.(2005). Belajar dan Faktor-faktor yang mempengaruhinya. Jakarta: RinekaCipta.

Sugiyono.(2007a).

Cara mudahmenyusunskripsi, tesis, dan disertasi. Bandung: Alfabeta. (2014b). Metode penelitian kuantitatif,kualitatif, dan $R \& D$. Bandung:Alfabet

Suharsimi Arikunto. (2010). Prosedur penelitian suatu pendekatan praktik. Jakarta : PT. Rineka Cipta

Sumiati dan Asra. (2009). Metode pembeljaaran. Bandung:Cv. Wacana Prima.

Suyanto dan Asep Jihad. (2013). Menjadi guru profesional. Strategi meningkatkan kualifikasi dan kualitas guru di era global. Jakarta: Erlangga.

Syaiful Bahri Djamarah dan Aswan Zain.(2006). Strategi Belajar mengajar. Jakarta: Rineka Cipta.

Suyono. (2014). Pembelajaran efektif dan produktif berbasis literasi: analisis konteks, prinsip, dan wujud alternative strateg iimplementasinya di sekolah. Malang: UNM.

Syaiful Sagala.(2006).Konsep dan makna pembelajaran. Bandung:Alfabet.

Tatta Herawati Daulae. (2014). Menciptakan pembelajaran yang efektif. Forum Paedagogik Vol. 06, No.02 Juli 2014.

Thursan Hakim. (2010). Belajar secara efektif. Jakarta:Pustaka Pembangunan Swadaya.

Warni Tune Sumar dan Intan Abdul Razak.(2016). Strategi pembelajaran dalam implementasi kurikulum berbasis soft skill. Yogyakarta: Penerbit Deppublish.

Wina Sanjaya.(2008). Kurikulum dan pembelajaran. Jakarta: Prenada Meida Group.

Winastwan Gora danSunarto.(2007). Pakematik. Strategi pembelajaran inovatif berbasis TIK.Jakarta: Elex Media Komputindo. 
Winarini Wilman Dahlan Mansoer. (2011). Hubungan kecerdasaan. Jakarta:Grasindo.

Winastwan Gora dan Sunarto.(2007). Pakematik. Strategi pembelajaran inovatif berbasis TIK.Jakarta: Elex Media Komputindo.

Wisnu Nugroho Aji. (2014). Model Pembelajaran Dick And Carrey Dalam Pembelajaran Bahasa dan Sastra Indonesia. Kajian Linguistik dan Sastra, Vol. 1 No. 2, Desember 2016, 119-126.

Yusuf Bilfaqihdan M. Nur Qomarudin. (2015). Strategi menyusun materi pembelajaran daring. Yogyakarta: Deepublish.

Zhou, J. Dan Guo, W. (2016). Imitation in undergraduate teaching and learning. The Journal of Effective Teaching Vol. 16 No. 3 2016 5-27.

\section{Profil Singkat}

INNA FELINDA kelahiran Banjarmasin 5 Februari 1990 sampai pendidikan terakhir s1 Pendidikan Sejarah 2007 